\title{
VALUE-ADDING AND OUTSOURCING ACTIVITIES IN SLOVENIAN MANUFACTURING COMPANIES
}

\author{
PALCIC, I., OJSTERSEK, R., FICKO, M. \& BUCHMEISTER, B.
}

Abstract: This manuscript deals with analysing value adding and outsourcing activities in Slovenian manufacturing companies. Our research is based on the data from the largest European manufacturing survey and it includes data from Slovenia. We have analysed manufacturing companies based on their decision to fully outsource part of their activities in terms of $R \& D$ and manufacturing, partly outsource these activities or keep them in-house. Based on that we have studied the decisions on outsourcing $R \& D$, production activities in regards to different company characteristics: competitive criteria, innovation activities, company performance etc. Our results show that strategic decision on outsourcing part of companies' activities has an important impact on different companies' characteristics.

Key words: Manufacturing company, Value-adding activities, Outsourcing, European manufacturing survey, Company performance
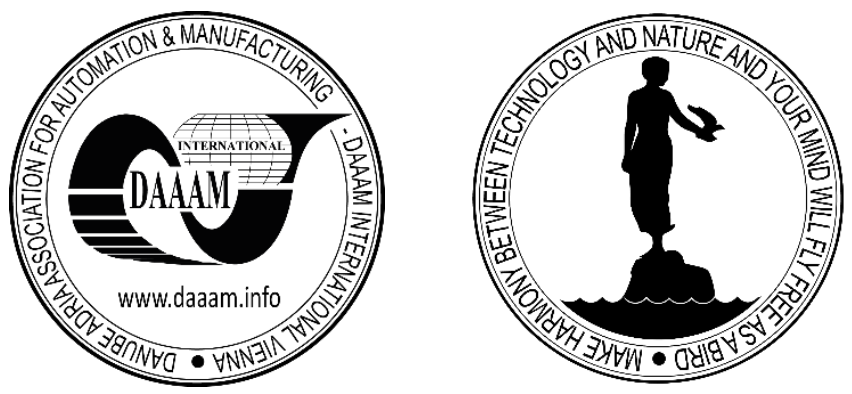

Authors' data: Assoc. Prof. Dr. Sc. Palcic, I[ztok]*; M. Sc. Ojstersek, R[obert]*, Assoc. Prof. Dr. Sc. Ficko, M[irko]*, Prof. Dr. Sc. Buchmeister, B[orut]*, * University of Maribor, Faculty of Mechanical Engineering, Laboratory for Production Management, Smetanova 17, SI - 2000, Maribor, Slovenia, iztok.palcic@um.si, robert.ojstersek@um.si,mirko.ficko@um.si, borut.buchmeister@um.si

This Publication has to be referred as: Palcic, I[ztok]; Ojstersek, R[obert]; Ficko, $\mathrm{M}$ [irko] \& Buchmeister, B[orut] (2018). Value-adding and Outsourcing Activities in Slovenian Manufacturing Companies, Chapter 11 in DAAAM International Scientific Book 2018, pp.119-130, B. Katalinic (Ed.), Published by DAAAM International, ISBN 978-3-902734-19-8, ISSN 1726-9687, Vienna, Austria

DOI: $10.2507 /$ daaam.scibook.2018.11 


\section{Introduction}

This manuscript focuses on the stages of value creation in Slovenian manufacturing companies. The value chain of a manufacturing company can start in the R\&D phase of new product development and is carried out through design, manufacturing, assembly, distribution and final sales activities. It is obvious that manufacturing companies do not carry out all these activities. It is also a fact that manufacturing company can carry out these activities in-house or are partially, largely or entirely outsourced to other parts of company (if existent) or to other companies / partners.

The practice of outsourcing is not new, but its importance has increased in recent years. Outsourcing is commonly defined as the transfer of activities and processes previously conducted internally to an external party (Ellram \& Billington, 2001) or as turning over all or part of an organizational activity to an outside vendor (Barthelemy, 2003). The scope of outsourcing has expanded over the past two decades from focussing solely on the procurement of non-core components and services to the outsourcing of every possible activity within the value chain, such as: first, production activities at different stages of production; second, production-supporting activities including research and development, engineering, marketing, quality control, human resource management; and third, ancillary activities such as inventories management, internal and distribution logistics, plant and machinery maintenance, and data processing (Gottfredson, 2005). When deciding to outsource parts of their manufacturing operations, companies must consider the implications for their competitive priorities, such as cost, quality, flexibility, speed and innovativeness (Gray et al., 2009; Hätonen \& Eriksson, 2009).

In this manuscript we are focusing on outsourcing of $R \& D$ and production activities. Strategic outsourcing deals with outsourcing of R\&D activities due to the lack of knowledge and skills, while operational outsourcing deals with outsourcing of parts of manufacturing and assembly activities due to lack of capacities and the need to increase flexibility. Manufacturing flexibility relates to volume flexibilities, that is, increase production volumes in terms of increased demand or cancelation of outsourcing contracts in times of low demand. Manufacturing flexibility can be achieved through, among other means, modular product designs, advanced manufacturing technologies, efficient changeovers, and outsourcing (Scherrer-Rathje et al., 2014).

Outsourcing has a positive effect in those times of increased demand because the company does not need to invest into additional capacities. Since today it is expensive to do the entire $R \& D$ and design in-house, there is a raise in outsourcing of $R \& D$ and design/engineering. At one side, keeping the $R \& D$ in-house is less risky but more expensive and may need longer times to give the final result - innovation. On the other hand outsourcing of R\&D might speed up the process and bringing new products in a more timely matter to the market (Scherrer-Rathje et al., 2014; Prester \& Palčič, 2017; Todic et al., 2017; Zhao et al., 2017). 
Research shows that outsourcing produces mixed results (Verwaal, 2017). It is also a fact that the majority of research on outsourcing is performed in developed countries (Größler et al., 2013). Therefore, we extended research on outsourcing in manufacturing companies in less developed country. We were interested in how often our manufacturing companies include R\&D activities in their value chain. We were also interested in the extent to which manufacturing companies carry out R\&D activities and production activities by themselves and to what extent they are left outsourced to external partners, and how these decisions affect different characteristics of companies.

\section{Research methodology}

Our analysis is based on data from European Manufacturing Survey (EMS), a survey on the diffusion of advanced production technologies and organisational concepts in the European manufacturing industry. EMS focuses on fields such as technical modernisation of value adding processes, introduction of innovative organisational concepts, including international offshoring/outsourcing and backshoring of production and $\mathrm{R} \& \mathrm{D}$ activities, and new business models for complementing the product portfolio with innovative services. The survey's questions concern manufacturing strategies, the application of innovative organisational and technological concepts in production, cooperation issues, production off-shoring and backsourcing, servitisation, and questions of personnel deployment and qualification. In addition, data on performance indicators such as productivity, flexibility, quality and returns is collected. EMS is coordinated by the Fraunhofer Institute for Systems and Innovation Research - ISI. The survey takes place every three years. In most countries, EMS is organised as a paper-based survey at company level (the core questionnaire has six pages). The persons contacted to fill in the questionnaires are the production manager or the CEO of the manufacturing companies. The responding companies present a cross-section of the main manufacturing industries. Included are producers of rubber and plastics, metal works, mechanical engineering, electrical engineering, textile and others. The survey is performed in manufacturing companies (NACE codes from 17 to 35) with at least 20 employees (Palčič \& Buchmeister, 2016).

Our research is based on EMS data from Slovenian subsample from the years 2015 and 2016. We sent 739 questionnaires and received 90 answers (12,30\% response rate). We have excluded companies from textile industry, thus receiving 85 responses with a $13 \%$ response rate. NACE divisions 22,25 and 28 are most widely represented with around $30 \%$ of companies from NACE 25 and around 15\% for each NACE 22 and NACE 28 division. The structure of manufacturing companies, based on their size, where the number of employees was the classifying criterion, has shown that the largest share of respondents is from medium sized companies (around 56\%), 25\% from small companies and $19 \%$ from large companies.

As can be seen from Figure 1, the manufacturing companies were divided into 4 groups according to the share of in-house contribution to value creation: 
- Group 1 - large extent: companies with mostly own activities ("in-house", over 85\% of activities within the company).

- Group 2 - partially outsourced: companies with a significant share of intracorporate activities (between $25 \%$ and $85 \%$ in-house contribution).

- Group 3 - large extent outsourced: companies that mostly leave out activities to external partners ("outsourcing", only up to $25 \%$ in-house contribution).

- Group 4 - not required in the value creation process: companies that do not have or do not need activities.

\begin{tabular}{|c|c|c|c|c|c|c|}
\hline \multirow{3}{*}{$\begin{array}{l}\text { Share of in-house } \\
\text { contribution } \\
\text { to value creation }\end{array}$} & $\begin{array}{l}\text { and } \\
\text { ntribu } \\
\text { lot nec }\end{array}$ & $\begin{array}{l}\text { cialization of } \\
\text { which have b } \\
\text { or your main pr }\end{array}$ & $\begin{array}{l}\text { your main product, wh } \\
\text { een outsourced? } \\
\text { oduct, please indicate it }\end{array}$ & $\begin{array}{l}\mathrm{ch} \text { of the fo } \\
\mathrm{n} \text { the last ro }\end{array}$ & stages of $\mathrm{t}$ & e creatio \\
\hline & \multicolumn{6}{|c|}{ Value creation stages: $\triangleright$ Please tick per row one box only } \\
\hline & R\&D & $\begin{array}{l}\text { Engineering/ } \\
\text { Design }\end{array}$ & $\begin{array}{c}\text { Manufacturing/ } \\
\text { Processing/Recycling }\end{array}$ & Assembly & $\begin{array}{l}\text { Packaging/ } \\
\text { Distribution }\end{array}$ & $\begin{array}{l}\text { Service } \\
\text { offer }\end{array}$ \\
\hline \multicolumn{7}{|l|}{$\begin{array}{l}\text { large extent } \\
86 \%-100 \% \text { in-house contribution }\end{array}$} \\
\hline \multicolumn{7}{|l|}{$\begin{array}{l}\text { partially outsourced } \\
25 \%-85 \% \text { in-house contribution }\end{array}$} \\
\hline $\begin{array}{l}\text { large extent outsourced } \\
0 \%-24 \% \text { in-house contribution }\end{array}$ & & & & & & \\
\hline $\begin{array}{l}\text { no required in the value } \\
\text { creation process }\end{array}$ & & & & & & 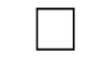 \\
\hline
\end{tabular}

Fig. 1. Question on value creation process in manufacturing companies

Based on this classification we formed groups of companies specifically for R\&D activities and for production activities. We also looked at the activities related to engineering/design, assembly, maintenance and service provision and packaging and distribution, but we are not dealing with them in this manuscript.

\section{Results and discussion}

Manufacturing companies were divided into 4 groups according to the share of in-house activities in the value-creation process with respect to $R \& D$ activities. A large proportion of companies were present in all groups, which enabled further analysis.

- Group 1 - companies with predominantly own R\&D activities (over $85 \%$ of activities within the company).

- Group 2-companies with a significant share of R\&D activities within the company (between $25 \%$ and $85 \%$ within the company).

- Group 3-companies that mainly relate R\&D activities to external partners (up to $25 \%$ within the company).

- Group 4-companies that do not have or do not need R\&D activities.

Figure 2 shows that almost $80 \%$ of manufacturing companies have $R \& D$ activities, with over a third of manufacturing companies having a full range of R\&D activities in-house. A good $13 \%$ of companies have a predominant share of R\&D activities in-house, and partly they carry out these activities in other parts of the company or by external partners. A good quarter of companies are those who need $R \& D$ activities, but they are carried out mainly elsewhere. 
When we prepared the distribution of companies by groups for the field of engineering and design, we found out that the distribution is relatively similar, with the share of manufacturing companies without engineering and design phase being only $12 \%$.

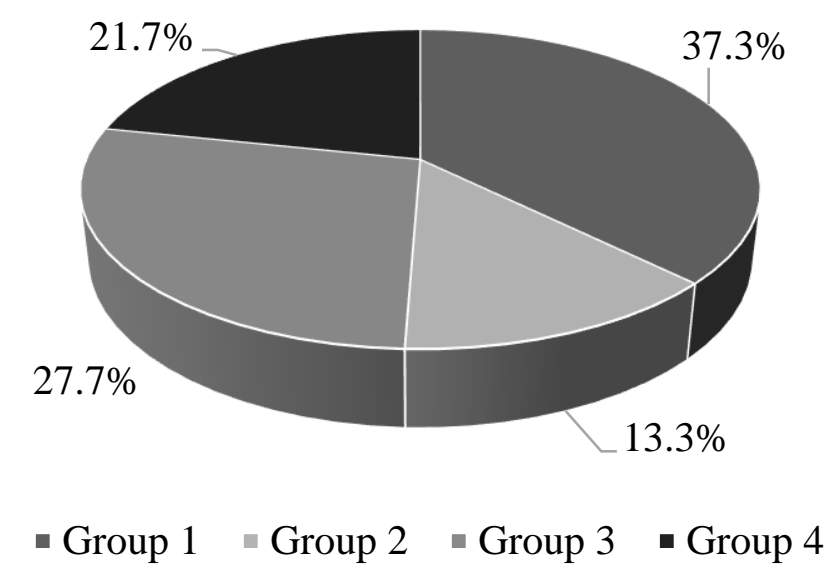

Fig. 2. Share of manufacturing companies based on outsourced R\&D activities

Manufacturing companies were divided into 2 groups according to the share of in-house activities in the value-creation process with respect to production activities. Since we are dealing with manufacturing companies, there are no representatives of group 4. Group 2 and group 3 were joined into one group.

- Group 1 - companies with predominantly own production activities (over 85\% of activities within the company).

- Group 2-3 - companies with a significant share of production activities within the company (between $25 \%$ and $85 \%$ in the company) and companies with minor share of production activities within the company (up to $25 \%$ in the company).

Figure 3 shows that the share of companies with predominantly in-house production activities is very large, almost $80 \%$. Only $4 \%$ of companies had the majority of production activities in outsourcing, $18 \%$ of manufacturing companies had a significant share of production activities within the company (all together, therefore, Group 2 and Group 3 have a $21.7 \%$ share).

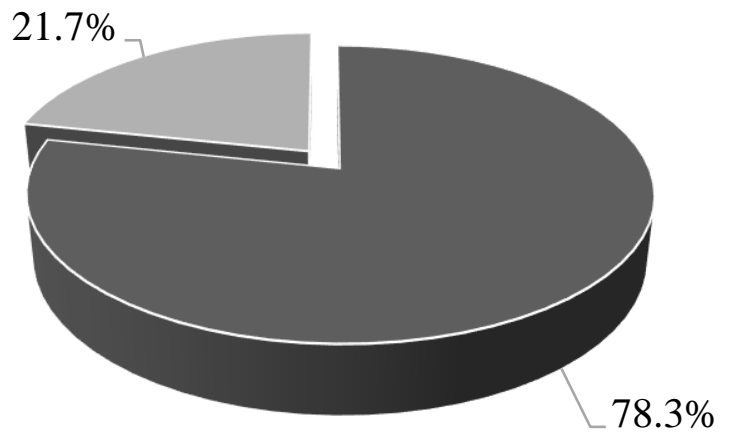

- Group 1 - Group 2-3

Fig. 3. Share of manufacturing companies based on outsourced production activities 
In the survey, manufacturing companies estimated which of the six competitive criteria offered are the most important for them. They decided between the product price, the product quality, ability to develop innovative products, customisation to customers' demands, adherence to delivery times/short delivery times and delivery of product-related services. Competitive criteria ranged from 1 to 6 , whereby rating 1 was for the most important competitive criterion. Tables 1 and 2 show the results for both cases examined.

\begin{tabular}{|c|c|c|c|c|c|c|}
\hline $\begin{array}{c}\text { Company } \\
\text { group }\end{array}$ & Product price & $\begin{array}{c}\text { Product } \\
\text { quality }\end{array}$ & $\begin{array}{c}\text { Innovative } \\
\text { products }\end{array}$ & $\begin{array}{c}\text { Customisation } \\
\text { to customers' } \\
\text { demands }\end{array}$ & $\begin{array}{c}\text { Adherence to } \\
\text { delivery } \\
\text { times/ } \\
\text { short delivery } \\
\text { times }\end{array}$ & $\begin{array}{c}\text { Product- } \\
\text { related } \\
\text { services }\end{array}$ \\
\hline Group 1 & $\mathbf{3 , 8 5}$ & $\mathbf{2 , 3 7}$ & $\mathbf{3 , 7 0}$ & $\mathbf{2 , 6 3}$ & $\mathbf{3 , 3 7}$ & $\mathbf{5 , 0 7}$ \\
\hline Group 2 & $\mathbf{3 , 6 7}$ & $\mathbf{2 , 1 1}$ & $\mathbf{4 , 1 1}$ & $\mathbf{3 , 2 2}$ & $\mathbf{3 , 4 4}$ & $\mathbf{4 , 4 4}$ \\
\hline Group 3 & $\mathbf{2 , 6 7}$ & $\mathbf{2 , 3 8}$ & $\mathbf{5 , 1 4}$ & $\mathbf{2 , 6 2}$ & $\mathbf{3 , 1 0}$ & $\mathbf{5 , 1 0}$ \\
\hline Group 4 & $\mathbf{3 , 9 3}$ & $\mathbf{2 , 2 9}$ & $\mathbf{5 , 0 0}$ & $\mathbf{2 , 2 1}$ & $\mathbf{2 , 9 3}$ & $\mathbf{4 , 6 4}$ \\
\hline
\end{tabular}

Tab. 1. Share of in-house R\&D activities and importance of competitive criteria

Table 1 shows that for manufacturing companies, in general, the most important competitive criterion is the product quality, and secondly, it is customisation to the customer's demands. The product price is just in fourth place. It can be noted that for companies that do not have $R \& D$ activities (Group 4) the customisation to the customer's demands is practically as important a competitive criterion as the product quality. We can also conclude that the competitive criterion development of innovative products in companies with less or no own $R \& D$ activities is an increasingly less important competitive criterion than in other groups.

\begin{tabular}{|c|c|c|c|c|c|c|}
\hline $\begin{array}{c}\text { Company } \\
\text { group }\end{array}$ & Product price & $\begin{array}{c}\text { Product } \\
\text { quality }\end{array}$ & $\begin{array}{c}\text { Innovative } \\
\text { products }\end{array}$ & $\begin{array}{c}\text { Customisation } \\
\text { to customers' } \\
\text { demands }\end{array}$ & $\begin{array}{c}\text { Adherence to } \\
\text { delivery } \\
\text { times/ } \\
\text { short delivery } \\
\text { times }\end{array}$ & $\begin{array}{c}\text { Product- } \\
\text { related } \\
\text { services }\end{array}$ \\
\hline Group 1 & $\mathbf{3 , 4 7}$ & $\mathbf{2 , 1 4}$ & $\mathbf{4 , 4 2}$ & $\mathbf{2 , 7 0}$ & $\mathbf{3 , 3 5}$ & $\mathbf{4 , 9 1}$ \\
\hline Group 2-3 & $\mathbf{3 , 5 7}$ & $\mathbf{3 , 0 7}$ & $\mathbf{4 , 5 0}$ & $\mathbf{2 , 2 9}$ & $\mathbf{2 , 6 4}$ & $\mathbf{4 , 9 3}$ \\
\hline
\end{tabular}

Tab. 2. Share of in-house production activities and importance of competitive criteria

Table 2 offers results that are even more interesting. We can see that for manufacturing companies, which have production mostly in-house, the most important competitive criterion is the product quality, while for other manufacturing companies, the customisation to the customer's demands is the most important competitive criterion. Adherence to delivery times/short delivery times is also more important competitive criterion than product quality.

Obviously, the fact that you do not have a real control over production affects the ability to ensure product quality. This is the trade-off that manufacturing companies that outsource or off-shore parts of their production must be aware of. The motive for outsourcing or even off-shoring production is often being more flexible to customers' demands, which can be assured if company moves a part of its production closer to customers. 
We also asked manufacturing companies to evaluate which innovation areas are most important for their company. Companies selected between the development and delivery of product-related services, the introduction of new organizational concepts, the introduction of technical innovations in the production process and the development of new products. The innovation areas ranged from 1 to 4 , with grade 1 for the most important area. Tables 3 and 4 show the results for both cases examined.

\begin{tabular}{|c|c|c|c|c|}
\hline Company group & $\begin{array}{c}\text { Complementing } \\
\text { product offers with } \\
\text { services }\end{array}$ & $\begin{array}{c}\text { New organizational } \\
\text { concepts }\end{array}$ & $\begin{array}{c}\text { New technical } \\
\text { production processes }\end{array}$ & New products \\
\hline Group 1 & 2,97 & 3,59 & 2,07 & 1,38 \\
\hline Group 2 & 2,67 & 2,89 & 2,67 & 1,78 \\
\hline Group 3 & 2,84 & 2,81 & 1,77 & 2,58 \\
\hline Group 4 & 2,79 & 3,14 & 1,64 & 2,43 \\
\hline
\end{tabular}

Tab. 3. Share of in-house R\&D activities and importance of innovation areas

Table 3 indicates that for companies with $R \& D$ activities entirely or predominantly in-house, the most important innovation area is related to the development of new products. In Groups 3 and 4, the most important area is the introduction of various technical innovations in the manufacturing company. If we look at Table 4, then the rank of relevance changes, as technical innovations in the production process are the most important area in companies that have production entirely or mainly in-house.

\begin{tabular}{|c|c|c|c|c|}
\hline Company group & $\begin{array}{c}\text { Complementing } \\
\text { product offers with } \\
\text { services }\end{array}$ & $\begin{array}{c}\text { New organizational } \\
\text { concepts }\end{array}$ & $\begin{array}{c}\text { New technical } \\
\text { production processes }\end{array}$ & New products \\
\hline Group 1 & 2,93 & 3,21 & 1,82 & 2,04 \\
\hline Group 2-3 & 2,53 & 3,13 & 2,20 & 2,13 \\
\hline
\end{tabular}

Tab. 4. Share of in-house production activities and importance of innovation areas

Next we will show the relationship between the share of in-house activities in the process of value creation and some specific characteristics of companies (Table 5 and Table 6).

\begin{tabular}{|c|c|c|c|c|c|}
\hline $\begin{array}{c}\text { Company } \\
\text { group }\end{array}$ & $\begin{array}{c}\text { Share of graduates } \\
\text { in the company } \\
{[\%]}\end{array}$ & $\begin{array}{c}\text { Share of } \\
\text { employees in } \\
\text { R\&D sector [\%] }\end{array}$ & $\begin{array}{c}\text { Introduction of } \\
\text { new products to } \\
\text { market in last 3 } \\
\text { years [\%] }\end{array}$ & $\begin{array}{c}\text { Share of } \\
\text { companies that } \\
\text { produced products } \\
\text { older than 10 } \\
\text { years [\%] }\end{array}$ & $\begin{array}{c}\text { Expenditures on } \\
\text { R\&D as share of } \\
\text { turnover [\%] }\end{array}$ \\
\hline Group 1 & 21,97 & 13,38 & 84 & 100 & 4,7 \\
\hline Group 2 & 17,20 & 10,56 & 55 & 82 & 2,6 \\
\hline Group 3 & 16,64 & 5,28 & 35 & 78 & 2,7 \\
\hline Group 4 & 13,38 & 1,38 & 44 & 100 & 0,3 \\
\hline
\end{tabular}

Tab. 5. Share of in-house R\&D activities and selected manufacturing companies characteristics

The first characteristic we observed is the share of employees in a manufacturing company with a high level of education. In Table 5, we see a clear link between the share of in-house R\&D activities and the share of employees with a high level of education. Less in-house $R \& D$ activities also means a lower share of highly educated staff. 
Something similar can also be seen in Table 6, where the share of employees with a higher education is higher in companies, where there are several production activities in outsourcing. This reflects the fact that these manufacturing companies stick to more in-house R\&D activities. A very similar picture is related to the question of the number of staff employed in the R\&D sector in the company and the amount of annual revenues invested by the company in R\&D activities. We explain the answers to these questions in the same way as the answer to the share of highly educated staff.

\begin{tabular}{|c|c|c|c|c|c|}
\hline $\begin{array}{c}\text { Company } \\
\text { group }\end{array}$ & $\begin{array}{c}\text { Share of graduates } \\
\text { in the company } \\
{[\%]}\end{array}$ & $\begin{array}{c}\text { Share of } \\
\text { employees in } \\
\text { R\&D sector [\%] }\end{array}$ & $\begin{array}{c}\text { Introduction of } \\
\text { new products to } \\
\text { market in last 3 } \\
\text { years [\%] }\end{array}$ & $\begin{array}{c}\text { Share of } \\
\text { companies that } \\
\text { produced products } \\
\text { older than 10 } \\
\text { years [\%] }\end{array}$ & $\begin{array}{c}\text { Expenditures on } \\
\text { R\&D as share of } \\
\text { turnover [\%] }\end{array}$ \\
\hline Group 1 & 16,49 & 5,05 & 58 & 91 & 3,0 \\
\hline Group 2-3 & 21,88 & 7,12 & 50 & 94 & 2,5 \\
\hline
\end{tabular}

Tab. 6. Share of in-house production activities and selected manufacturing companies characteristics

The ability of companies to introduce new products to the market was determined by asking companies whether they introduced a new product in the period from 2012 to 2015. Table 5 clearly indicates that the share of companies that have introduced a new product on the market over a period of three years is higher in the group of companies with higher share of in-house R\&D activities. The share of in-house production activities does not have a major impact on the ability to introduce new products to the market.

We also asked companies whether they still produce products that they have been in the production program for 10 years or more. We got a somewhat surprising results in Table 5, where manufacturing companies, with predominantly in-house R\&D activities, still manufacture products, that have been a part of production program for more than 10 years. Generally, more than $80 \%$ of Slovenian manufacturing companies still manufacture products that are 10 or more years as a part of companies' production program. This number is not higher than, for example, in Austria or Germany.

We have analysed the characteristics of manufacturing companies according to the OECD's taxonomy of manufacturing industries classified by their technological intensity (OECD, 2005). We have formed two groups:

- "Low and Medium-Low technology" (LMT) with companies from NACE 22, 23, 24, 25 and 32. This group included 54\% of all companies.

- "Medium-High and High technology" (MHT) with companies from NACE 26, 27, 28, 29 and 30. This group included $46 \%$ of all companies.

Figure 4 clearly shows that the share of companies with predominantly in-house $R \& D$ activities is much higher in MHT industries. In these industries, R\&D activities are even more important for developing new products that are more complex and have higher added value. The relationship is, of course, turned around in Groups 3 and 4, where companies from LMT industries often give $R \& D$ activities to a large extent or even completely out or do not even need them at all. 


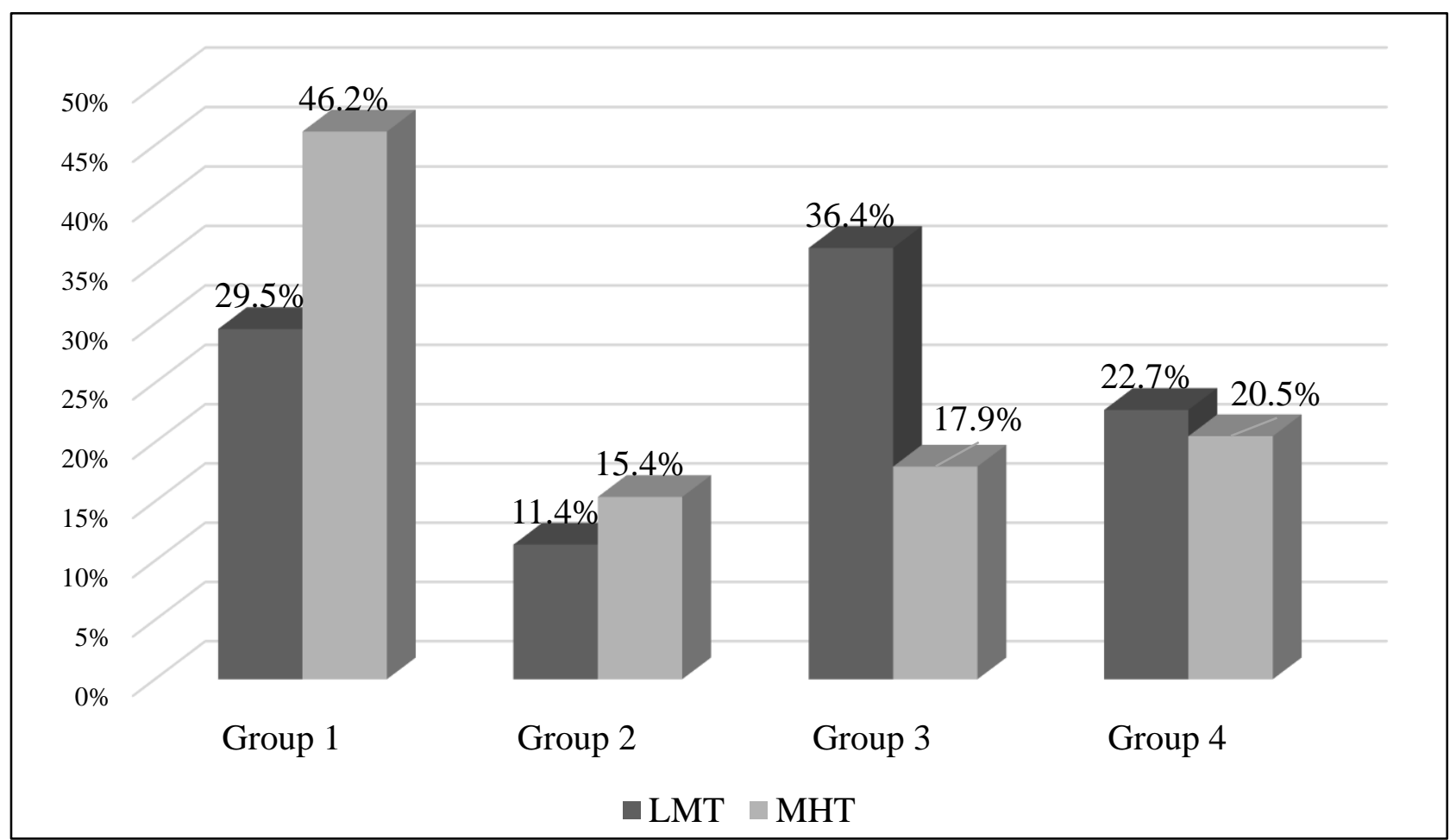

Fig. 4. Company characteristics based on share of in-house R\&D activities and technological intensity

Figure 5 shows that the share of companies with predominantly in-house production activities is a bit higher in manufacturing companies from the LMT industry, while MHT manufacturing companies are more likely to opt for outsourcing of production activities.

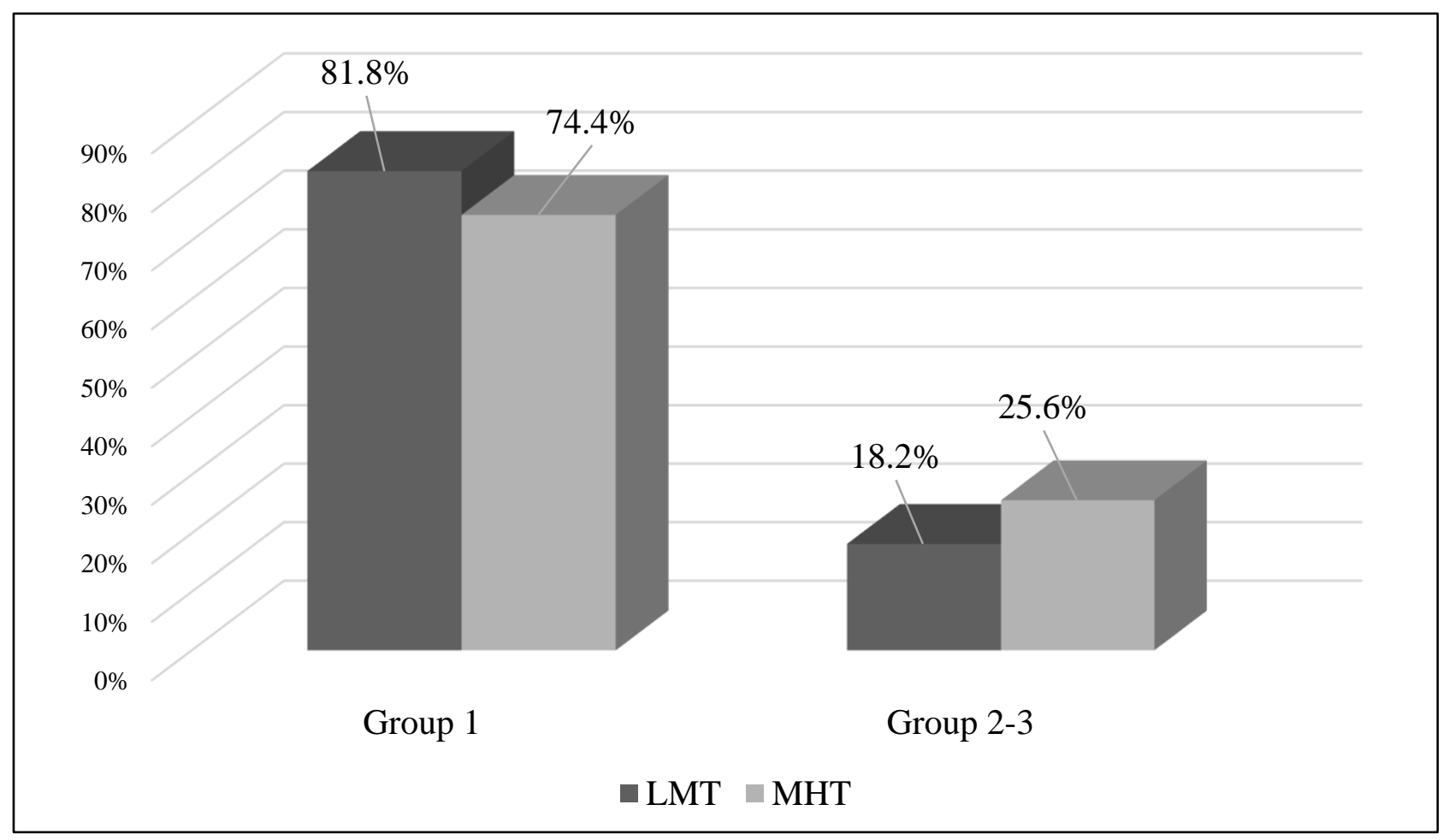

Fig. 5. Company characteristics based on share of in-house production activities and technological intensity 


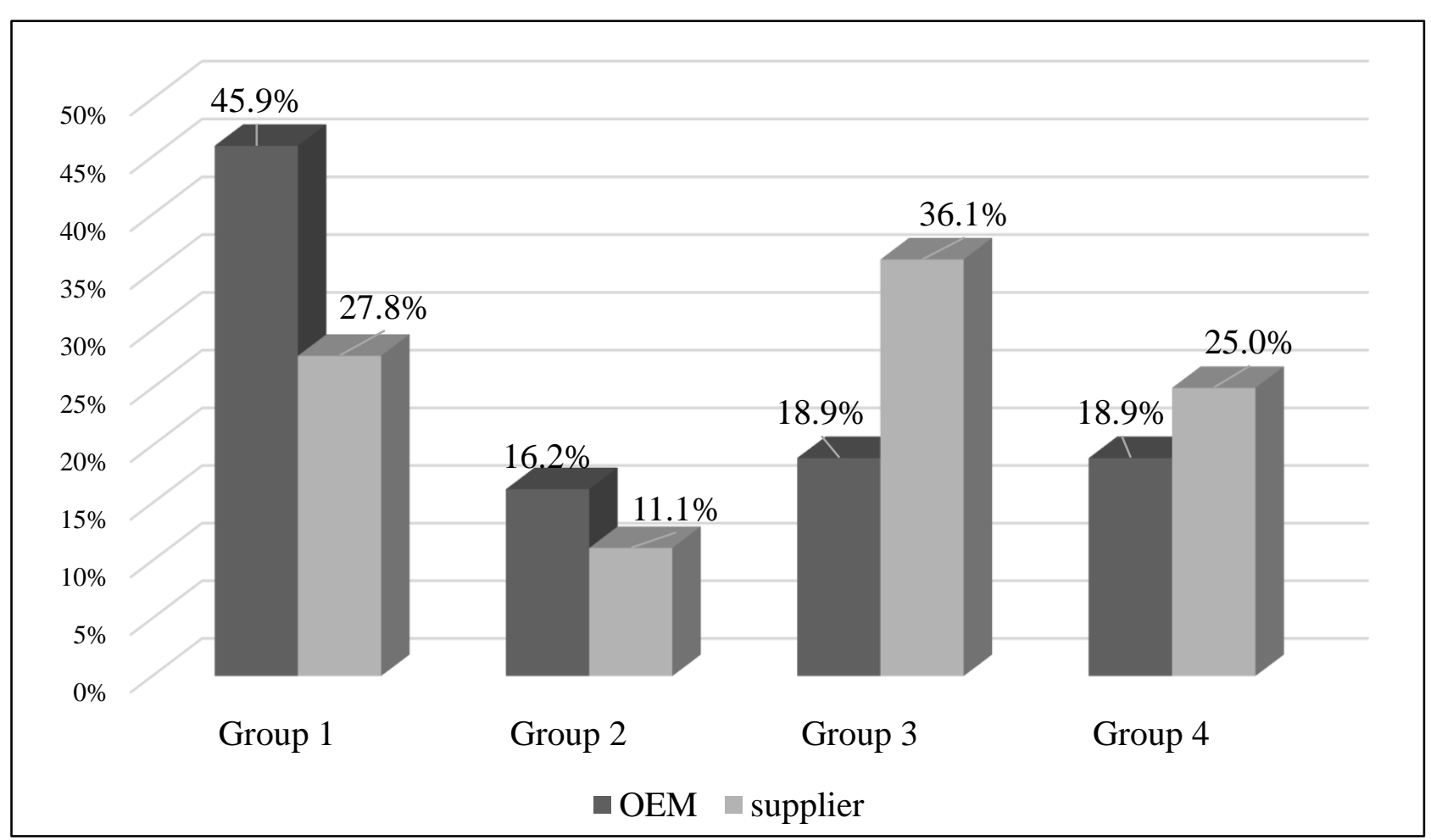

Fig. 6. Company characteristics based on share of in-house R\&D activities and OEM/supplier status

We upgraded our analysis by observing the use of technology concepts in the light of the fact whether the manufacturing company is a manufacturer of final products (OEM) or supplier. In our sample each group had a 50\% share. Figure 6 shows that the share of companies that have in-house R\&D activities is much higher in OEMs than in suppliers, or vice versa suppliers leave some of their R\&D activities to others, or even do not even need them. This clearly indicates that suppliers often only perform production activities for their customers.

\section{Discussion and conclusion}

The results of our research have shown some interesting and important links between the decisions of the company, to what extent keep R\&D activities and production activities in-house, as well as the selected characteristics of companies. The product quality today is clearly the main competitive criterion of the company regardless of the share of $R \& D$ activities that the companies carry out. Our research showed that half of the manufacturing companies have a major share of $R \& D$ activities in-house. For these companies, innovation in product development and the ability to develop new products is crucial. Such companies also have a higher share of highly educated staff and invest a higher share of their revenues in R\&D activities. For companies with predominantly own production activities, investments in technical innovations in the production process are more important than innovation in product development. In these companies product quality is the most important competitive criterion. We can conclude that assuring product quality requires in-house production activities and large investments in production process. 
Higher technological intensity of the manufacturing company and predominantly in-house R\&D activities are highly positively correlated. Companies from mediumlow and low industries are more inclined to outsource their R\&D activities. On the other hand, we found no direct relationship between technological intensity and outsourcing strategy of production activities. There is also an important difference between OEMs and suppliers, where the share of manufacturing companies that have in-house R\&D activities is much higher in OEMs than in suppliers, suggesting that suppliers often lack R\&D capacities and are only used as a production capacity for their customers.

We have looked at the relationship between the level of R\&D activities and production activities outsourcing in terms of some additional characteristics. We were also interested in the relationship with the product complexity. We identified three types of products in terms of complexity, where the assessment of the product complexity was made by companies: simple products (few components, few different materials, conventional technologies), medium complex products (e.g. pumps, a large number of parts and technologies used, easy assembly) and complex products (e.g. machines, a large number of components, materials, technologies used, demanding assembly). The main conclusion was that manufacturing companies that have $R \& D$ activities completely or predominantly in-house manufacture simple products less often. This finding is not surprising as we can relate strong in-house $R \& D$ activities to the ability to manufacture products that are more complex.

The size of the company did not have a significant impact on the outsourcing of $\mathrm{R} \& \mathrm{D}$ activities, while in production activities we found that companies that retain production activities in-house are on average larger than those companies that outsource part of their production to partners. The last relationship we have studied was the impact of outsourcing on the business performance of companies, which we have measured using the indicator on the return on sales (ROS). We found that there were practically no differences between all four groups of companies in terms of integrating $R \& D$ activities into their value chain. It was very similar for both groups of production activities. From this we can conclude that companies that do not have their own R\&D activities still have a business model that enables them to develop and manage the company towards success.

Regardless of the last finding that the level of outsourcing does not directly affect the business performance of companies, we have found quite a few interesting links between outsourcing and the characteristics of companies that can help management in making future strategic decisions. In the future, we will extend our research to other countries within our consortium with the aim of comparing the situation in Slovenian manufacturing companies to companies in Western European and Eastern European countries.

\section{Acknowledgements}

The authors acknowledge the financial support from the Slovenian Research Agency (research core funding No. P2-0190). 
Palcic, I.; Ojstersek, R.; Ficko, M. \& Buchmeister, B.: Value-adding and Outsourci...

\section{References}

Barthelemy, J. (2003). The seven deadly sins of outsourcing, Academy of Management Executive, Vol. 17, No. 2, pp. 87-100

Ellram, L. \& Billington, C. (2001). Purchasing leverage considerations in the outsourcing decision, European Journal of Purchasing \& Supply Management, Vol. 7, No. 1, pp. 15-27

Gottfredson, M.; Puryear, R. \& Phillips, S. (2005). Strategic sourcing: from periphery to the core, Harvard Business Review, Vol. 83, No. 2, pp. 132-139

Gray, J. V.; Roth, A. V. \& Tomlin, B. (2009). The influence of cost and quality priorities on the propensity to outsource production, Decision Sciences, Vol. 40, No. 4, pp. 697-726

Größler, A.; Laugen, B. T.; Arkader, R. \& Fleury, A. (2013). Differences in outsourcing strategies between firms in emerging and in developed markets, International Journal of Operations \& Production Management, Vol. 33, No. 3, pp. 296-321

Hätonen, J. \& Eriksson, T. (2009). 30 years of research and practice of outsourcing exploring the past and anticipating the future, Journal of International Management, Vol. 15, No. 2, pp. 142-55

OECD. (2005) Directorate for Science, Technology and Industry, stan indicators (2005 edition): 1980-2003. Organisation for Economic Co-operation and Development, Paris, France. Available from: http://www.oecd.org/industry/industryandglobalisation/40230754.pdf Accessed: 2016-07-01.

Palčič, I. \& Buchmeister, B. (2016). Energy and material saving technologies in Slovenian manufacturing firms, Annals 2016, 27th International DAAAM Symposium "Intelligent Manufacturing \& Automation", 23/30 206, October 2016, Mostar, Croatia, Katalinic, B. (Ed.), pp. 1-6, DAAAM International Vienna, Austria

Prester, J. \& Palčič, I. (2017). Outsourcing of R\&D versus operational outsourcing and its effects on flexibility and time to market, Euroma2017, 24th EurOMA conference, 01/05 July 2017, Edinburgh, Scotland, pp. 1-10

Scherrer-Rathje M.; Deflorin, P. \& Anand, G. (2014). Manufacturing flexibility through outsourcing: effects of contingencies, International Journal of Operations \& Production Management, Vol. 34, No. 9, pp. 1210-1242

Todic V.; Cosic I.; Maksimovic R.; Tasic N. \& Radakovic N. (2017). Model for Simulation of Life Cycle Costs at the Stage of Product Development, International Journal of Simulation Modelling, Vol. 16, No. 1, pp. 108-120

Verwaal, E. (2017). Global outsourcing, explorative innovation and firm financial performance: A knowledge-exchange based perspective, Journal of World Business, Vol. 52, No. 1, pp. 17-27

Zhao J. Y.; Wang Y. J.; Xi X. \& Wu G. D. (2017). Simulation of Steel Production Logistics System Based on Multi-Agents, International Journal of Simulation Modelling, Vol. 16, No. 1, pp. 167-175 